УДК $519.1+612.089$

DOI: https://doi.org/10.11603/mie.1996-1960.2018.3.9462

\title{
КАРДІОЛОГІЧНІ АСПЕКТИ МЕРЕЖЕВОЇ МЕДИЦИНИ
}

\author{
О. П. Мінцер, В. М. Заліський \\ Національна медична академія післядипломної освіти імені П. Л. Шупика \\ ${ }^{1}$ ДУ «Національний науковий центр «Інститут кардіології \\ імені академіка М. Д. Стражеска» НАМН України»
}

\begin{abstract}
У статті подано короткий огляд основних публікацій із мережевої медицині та застосування комплексного мережевого аналізу білкових взаємодій у вивченні захворювань людини. 3 огляду на функціональні взаємозалежності між молекулярними компонентами в клітині людини, захворювання рідко є наслідком аномалії в одному гені, але відображає комплексні аномалії внутрішньоклітинної мережі. Нові інструменти мережевої медицини пропонують платорорму для системного вивчення не лише молекулярної складності конкретного захворювання (що веде до ідентисрікації модулів і шляхів захворювання), але також і молекулярних відносин між явно вираженими (патогенними) френотипами.

Постулюється, що, виявляючи нові гени захворювань, необхідно визначати біологічну значимість пов'язаних із захворюванням мутацій, виявлених у результаті досліджень геному в цілому, та повного секвенування геному, а також виявлення мішеней і біомаркерів складних захворювань.

Робиться також висновок, що мережева медицина й онтологія знань мають багато спільного як у стратегії створення, так і в технологіях використання. Проте завдання багатовимірного моделювання сьогодні переважно виконуються в стратегії «онтологія знань». Те ж можна сказати й про освіту, де онтологічні рішення більш популярні.

Увагу приділено питанням мережевого взаємозв'язку різних кардіологічних захворювань на молекулярному та френотипічному рівнях. Багато захворювань серця розглядаються за допомогою комплексних клінічних фенотипів, що формуються в результаті інтегративного впливу на молекулярному (інтерактомному), генетичному (геномному) та екологічному (метаболомному) рівнях.
\end{abstract}

Ключові слова: мережева медицина, захворювання серця, мережевий аналіз, міждисциплінарний підхід, внутрішньоклітинна сигналізація, мульти «оміксні» дані, молекулярні мережі, біоінформаційний ресурс, онтології знань.

\section{CARDIOLOGIC ASPECTS OF NETWORK MEDICINE}

\author{
O. P. Mintser, V. M. Zalisky ${ }^{1}$ \\ Shupyk National Medical Academy of Postgraduate Education \\ ${ }^{1}$ National Scientific Center «M. D. Strazhesko Institute of Cardiology» NAMS of Ukraine
}

Background. The article provides a brief overview of the main publications on networked medicine and the application of an integrated network analysis of protein interactions in the study of human diseases. Given the functional interdependencies between the molecular components in a human cell, the disease is rarely a consequence of an anomaly in one gene, but reflects a complex anomaly of the intracellular network. New tools of network medicine offer a platform for a systematic study not only of the molecular complexity of a specific disease, leading to the identification of modules and pathways of the disease, but also the molecular relationships between manifestly (pathogenic) phenotypes.

Results. The purpose of the study: summarize the results of using the methodology of network medicine, primarily in cardiology.

It is postulated that, when revealing new disease genes, it is necessary to determine the biological significance of disease-related mutations identified as a result of genome studies as a whole, and complete sequencing of the genome, as well as for detection of targets and biomarkers of complex diseases.

Conclusions. Network medicine and the ontology of knowledge have much in common both in the creation strategy and in the technologies of use. However, the tasks of multidimensional modeling are now preferably performed in the «knowledge ontology» strategy. You can also say about education, where ontological solutions are more popular.

Attention is given to the issues of network interconnection of various cardiac diseases at the molecular and phenotypic level. Many diseases of the heart are examined with the help of complex clinical phenotypes formed as a result of integrative influence on the molecular (interactive), genetic (genomic) and ecological (metabolic) levels.

Key words: network medicine, cardiac diseases, network analysis, interdisciplinary approaches, intracellular signaling, multi «omics» data, molecular networks, bioinformatic resource, knowledge ontology. 


\title{
КАРДИОЛОГИЧЕСКИЕ АСПЕКТЫ СЕТЕВОЙ МЕДИЦИНЫ
}

\author{
О. П. Минцер, В. Н. Залесский ${ }^{1}$ \\ Национальная медицинская академия последипломного образования имени П. Л. Шупика

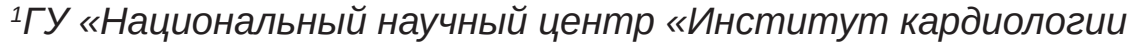 \\ имени академика Н. Д. Стражеско» НАМН Украины»
}

\begin{abstract}
В статье представлен краткий обзор основных публикаций по сетевой медицине и применению комплексного сетевого анализа белковых взаимодействий в изучении заболеваний человека. Учитывая функциональные взаимозависимости между молекулярными компонентами в клетке человека, заболевание редко является следствием аномалии в одном гене, но отражает комплексные аномалии внутриклеточной сети. Новые инструменты сетевой медицины предлагают платсорму для систематического изучения не только молекулярной сложности конкретного заболевания (приводит к идентификации модулей и путей заболевания), но также и молекулярных отношений между явно выраженными (патогенными) фенотипами.

Постулируется, что, выявляя новые гены заболеваний, необходимо определять биологическую значимость связанных с заболеванием мутаций, выявленных в результате исследований генома в целом, и полного секвенирования генома, а также выявления мишеней и биомаркеров сложных заболеваний.

Сделан вывод о том, что сетевая медицина и онтология знаний имеют много общего, как в стратегии создания, так и в технологиях использования. Однако задачи многомерного моделирования в настоящее время предпочтительно выполняются в стратегии «онтология знаний». То же можно сказать и об образовании, где онтологические решения более популярны.

Внимание уделено вопросам сетевой взаимосвязи различных кардиологических заболеваний на молекулярном и фенотипическом уровне. Многие заболевания сердца рассматриваются с помощью комплексных клинических френотипов, фрормирующихся в результате интегративного влияния на молекулярном (интерактомном), генетическом (геномном) и экологическом (метаболомном) уровнях.
\end{abstract}

Ключевые слова: сетевая медицина, заболевания сердца, сетевой анализ, междисциплинарный подход, внутриклеточная сигнализация, мульти«омиксные» данные, молекулярные сети, биоинформационный ресурс, онтологии знаний.

Вступ. Під терміном «мережева медицина» зазвичай розуміється наукова дисципліна, що стрімко розвивається та заснована на мережевому об'єднанні масивів даних клінічних і функціональних досліджень [26]. Ї̈̈ основні завдання пов'язані з ідентифікацією стану пацієнта, запобіганням ускладнень і лікуванням захворювань. Ця сфера зосереджується на використанні мережевої топології і мережевої динаміки в ідентифікації хвороб і розробці відповідних лікарських засобів [59]. Основним принципом мережевої медицини (i, більш глобально, системної біології) є використання методів математичного моделювання для розуміння мережевих процесів молекулярної, генетичної, клітинної та тканинної взаємозалежності $[1,4,15,68]$. Отже, методологічно мережева медицина використовує логіку мережевої топології і мережевої динаміки, що дозволяє прогнозувати перебіг патологічного процесу, можливі ускладнення та результати.

Минуло перше десятиліття після запропонованої концепції мережевої медицини [11] і мережевий підхід у медицині, що революціонізував, виявився вельми істотним [34].
Насамперед, філософія «мережевої медицини» забезпечила краще розуміння захворювань людини на системному рівні. До того ж, було висловлено припущення, що мережева медицина може запропонувати необхідні передумови для використання системного підходу в лікувальних і діагностичних інноваційних рішеннях [25]. Виявилося, що фармакологічні програми також можуть розвиватися в рамках мережевого підходу завдяки створенню лікарських засобів (ЛЗ), що включають білки - peгулятори внутрішньоклітинних сигнальних шляхів [42]. Пізніше було звернуто увагу на мережеві білок-білкові взаємодії у виробництві лікарських засобів [66]. Запропоновано навіть оригінальний тренд мережевої медицини «думай глобально, дій локально» з метою обліку фенотипічних ознак захворювання в рамках глобального регулювання на мережевому рівні [10]. Сьогодні цільовий ресурс мережевої медицини включає виявлення біомаркерів, створення нових препаратів, прогнозування побічних ефектів ліків, розроблення нових методів діагностики та лікування [54]. Відзначено важливість мережевого підходу для розуміння патогенезу захворювань на основі використання інформаційних технологій у медицині $[3,4,18]$. 
Мета дослідження: узагальнити підсумки використання методології мережевої медицини, насамперед, у кардіології.

Результати та їх обговорення . Міждисциплінарний підхід у мережевій медицині виявився вкрай важливим, оскільки забезпечив інтеграцію експериментальних і обчислювальних технологій збору та аналізу медичних даних [4, 9].

Дані в мережевій медицині часто застосовуються для математичного моделювання та багаторівневої інтеграції діагностики подій в епігеноміці, трансцитоміці, протеоміці та інших «оміках» за впливу мережевих елементів процесу внутрішньоклітинної сигналізації в органелах, клітинах, тканинах і органах [2, 5, 7, 44, 67]. При проведенні досліджень методами математичного моделювання інформація, що часто надходить, використовується для адаптації процесу збору даних біомедичних вимірювань і їх інтеграції з мережевими реакціями щодо хворого організму [57]. Отже, для успішного системного аналізу в мережевій медицині потрібно застосовувати інтердисциплінарний або навіть трансдисциплінарний підхід.

3 огляду на процеси еволюції, структуру і механізми функціонування мереж внутрішньоклітинної сигналізації (угрупування сигнальних молекул), можна точно позиціонувати білкові компоненти (білок-білкові взаємодії між глобулярними доменами і короткими лінійними пептидними мотивами), що грають ключову роль в ініціації і розвитку хвороби [17, 20, 22, 31]. У багатьох випадках ці компоненти не мають прямого відношення до конкретного захворювання, проте їх стимуляція або пригнічення може надавати благотворний вплив на сигнальні шляхи в клітинних мережевих структурах [13]. Водночас, фармакологічна модуляція процесів сигналізації у клітинних мережах може вплинути на стійкість клітин до патологічних стимулів, підвищуючи функціональну надійність здорових і знижуючи стійкість пухлинних клітин до хіміотерапії [29].

Необхідно відзначити, що в центрі уваги мережевої медицини знаходяться й альтеративно змінені мережі молекул внутрішньоклітинної сигналізації, що сприятимуть розвитку патологічного процесу. Ця сфера є одним із напрямів, де мережеві підходи можуть допомогти в отриманні додаткової цінної інформації для вивчення онтогенезу. Наприклад, міжклітинні зв’язки між білками, що зв’язані з мембраною та які секретуються, виявили здатність деяких фібробластів отримувати пухлинний фенотип [40].

Вельми взаємопов’ язаний характер взаємодії на молекулярному рівні означає, що важко (якщо не суперечити інтуїції) вважати хвороби незмінно незалежними одна від одної. Дійсно, різні модулі хвороби можуть перекриватися, так що вплив, викликаний одним захворюванням, може впливати на інші модулі хвороб [14]. Систематичне картування таких мережевих залежностей між патологічними фенотипами та їх модулями хвороби привело до появи концепції хвороби [12], що представляє карти хвороб, вузли яких є захворюваннями, а зв’язки яких є різними молекулярними зв’ язками між сполученими з хворобою клітинними компонентами. Розкриття таких зв'язків між захворюваннями не тільки допомагає нам зрозуміти, як різні фенотипи, що часто фігурують у різних медичних субдисциплінах [36], пов’язані на молекулярному рівні, але також може допомогти зрозуміти, чому певні групи захворювань виникають разом. Супутня захворюваність ідентифікує умови їх виникнення та пропонує ідеї, що можуть дати нові підходи до профілактики, діагностики та лікування захворювань. Підходи, засновані на методі, можуть також допомогти у відкритті Л3, зокрема коли йдеться про використання схвалених ліків для лікування молекулярно пов'язаних захворювань. Потім ми розглянемо побудову таких карт хвороб і наслідки спостережуваних асоціацій захворювань. Серед ключових завдань для мережевої медицини, пов'язаних з онкогенезом, $є$ подолання труднощів терапії пухлин $з$ трансформованими шляхами сигнальної трансдукції у бластомних клітинах [24, 28]. Однак, як це не парадоксально, протипухлинні препарати можуть сприяти стійкості ракових клітин (а не їх ослабленню) шляхом активізації сигнальних шляхів білок-білкової взаємодії у бластомних клітинах різної токологічної архітектури, пригнічуючи функціонування контурів керування біологічного зворотного зв'язку [46].

Якщо раніше дослідники - біохіміки звертали увагу на ферменти та їх альтернативні копії (ензимопатії), то на сьогодні основна увага пов’язана з вивченням впливу змін білків сигнальних шляхів на функціонування ферментів на системному рівні [56].

Одним із ключових ферментів основних сигнальних шляхів (multipathway) перехресного аналізу (crosstolks) [63], а також таргетних білків клітинних сигнальних шляхів [42] є кінази. Кіназні домени та 
їхні цільові мотиви (наприклад, специфічні послідовності амінокислот у білковому субстраті) добре відомі і зібрані в такі біоінформаційні ресурси, як Phosphosite i dbPAF [19], для системного виявлення й аналізу в мережі кіназ і фосфопротеїнів за допомогою обчислювального алгоритму NetPhorest [32].

Методи порівняльної фосфопротеоміки дозволили краще розуміти роль сигнальних білків у нормальному клітинному зростанні та пухлинній трансформації [43]. Порівняно недавно дані повнокомплектного секвенування були використані для прогнозування впливів генних мутацій, які змінюють мережеві властивості білків сигнальних шляхів і зумовлюють виникнення пухлинного фенотипу [21].

Як зазначено в роботі [51], системний підхід дозволяє просувати домінуючу роль фосфатаз як регуляторів просторово-часового проведення систем фосфорилювання білків у клітинах (як локально, так і дистантно), що дозволяє використовувати їх як терапевтичні лінії на системному рівні. Розроблено [35] стратегію фосфатому (phosphatome) людини, що дозволяє оцінити значення участі фосфатаз у механізмах регуляції гомеостазу фосфопротеїнів на основі зіставлення продуктів функціонування мережевих генів у процесі фенотипічного скринінгу набору генів людини, які містять домени фосфатаз і модулюють активність специфічних сигнальних шляхів розвитку внутрішньоклітинних процесів клітинного росту. При цьому програмне забезпечення CellNOpt (Cell Net Optimizer) [30] дозволяє оптимізувати узгодженість між логічними моделями передбачень і наборами експериментальних даних із загальною візуалізацією мережевих моделей клітинного росту.

Як відомо, кінази, фосфатази та інші ферменти специфічно зв'язуються зі своїми білковими субстратами i/або регуляторними пептидними мотивами. Також мотиви, зазвичай у вигляді коротких залишків, локалізовані в невпорядкованих областях функціональних модулів захворювань (кластерів), що є частиною інтерактомної мережі [6]. Найбільш повним сховищем пептидних мотивів є ресурс SLiMs (ELM, http./elm/en.org), розроблений для їх збору, зберігання та застосування [58]. Гнучкість даного сайту зв'язування різних конформаційних особливостей білкових регіонів дозволяє за допомогою якірного (anchor) способу прогнозування здійснювати прогноз невпорядкованості цільових регіонів вторинної структури білка.
Сканування кількох сотень протеомів показало, що виникнення невпорядкованості зв'язування істотно підвищується з виникненням патологічних змін в організмі, порівняно з процесом невпорядкованого зв’ язування в здоровому організмі [37].

Передбачення конформаційних змін невпорядкованих білків, пов'язаних із онкогенезом, дозволило виявити роль білків теплового шоку в кооперації 3 мережевими білками сигнальної трансдукції при імунотерапії злоякісних новоутворень [65]. Як передбачається, лінійні пептидні мотиви (не більше ніж 10 залишків), що виникають спочатку в невпорядкованих областях і відображають посттрансляційні зміни структури доменів, можуть бути індукторами мутацій у глобулярних білкових доменах, які призводять до виникнення онкологічного процесу [23].

Білкові молекули в складі скаффолдів - біоінженерних платформ за взаємодії з білками клітинної сигналізації дозволяють створювати надійні центри обробки сигналів у мережевих структурах скаффолду, як природних, так і штучних [50]. Однак, незважаючи на зростаючу кількість конкретних прикладів найважливіших білків біоінженерних плейферм (зокрема білків сигнальних шляхів; ферментів модифікаторів ендосом: фосфатаз, убіквітинлігаз; а також транскрипційних і посттранскрипційних регуляторів) у сигнальному ресурсі скаффолдів, масштаб і складність здійснених теперішніх експериментальних підходів $€$ не достатніми для оптимального усвідомлення системних ефектів за використання білків - скаффолдів у лікуванні захворювань [52].

Кількісне моделювання — побудова логіко-математичних моделей молекулярних мереж у клітині отримує розвиток на основі зміни базових масивів даних, отриманих у результатах використання прямих методів молекулярної візуалізації in vivo [55]. Вони включають методи світлооптичного (FA, fluorescence analysis; FRAP, fluorescence recovery after photobleaching; FLIP, fluorescence loss in photobleaching; FCS, fluorescence correlation spectroscopy; FRET, fluorescence resonance energy transfer), акустооптичного, КТ (комп’ютернотомографічного), МРТ (магнітно-резонансно томографічного), ПЕГ (позитронно-емісійно томографічного), ОФЕКТ (однофотонно-емісійно комп’ютерно-томографічного) та інших методів прижиттєвої візуалізації [2, 47].

На сьогодні уявлення про скоординовані реакції і дії низки молекул сигнальної трансдукції 
у клітині істотно розширилися завдяки розробці інструментів для візуалізації та аналізу молекулярних мереж, шляхів і оміксних даних [49, 64]. Вони використовуються в спеціалізованих базах великої місткості для зберігання і систематизації молекулярно-біологічних даних (PHOSIDA, PhosphoSitePlus, Phospho.ELM, Net-PhosK, Predikin, Scansite - білок-білкової взаємодії; EDGEdb, REDfly, JASPAR, ENCODE, PAZAR, ABS, ORegAnno - транскріпційно-регуляторної взаємодії; miRBase, PutMir, miRanda, Target Scan, miRecords - мікроРНК / мРНК-мішеней). Багато 3 цих баз даних є універсальними в спеціалізованих сферах знань, проте вони не забезпечують позиціонування комплексної картини багаторівневої регуляції і вимагають зусиль міждисциплінарних фахівців [30] для краудсорсингу з метою генерації високоякісних надійних результатів.

Комплексний підхід до мережевого моделювання передбачає для підвищення ефективності мережевого аналізу залучення широкого кола дослідників різних спеціальностей (за межами основної групи). Така технологія, як відомо, отримала назву краудсорсингу і в ряді випадків дозволяє оптимізувати / реконструювати клітинні сигнальні мережі для передбачення подій з експресії генів у сфері реверс-інжинірингу (зворотної інженерії білків і генних мереж) [53]. Поряд із DREAM в академічних дослідженнях у рамках мережевої медицини отримали розвиток такі краудсорсингові ініціативи, як CAPRI (Critical Assessment of Prediction of Interaction) - критична оцінка передбачення третинної структури білка, FlowCAP (Critical Assessment of Automated Flow Cytometry data analysis) — критична оцінка аналізу даних методу автоматизованої проточної цитометрії [30].

Мережевий аналіз регулярних молекул отримав інтенсивний розвиток при вивченні патогенетичних механізмів багатьох захворювань людини [45] і включає в себе дані з хронічної обструктивної хвороби легень [8], пухлин молочної залози [60], шлунково-кишкових розладів при хворобі Крона [61], а також дані з ідентифікації молекул-мішеней за реалізації фармакотерапевтичних програм [39].

Використання принципів мережевого аналізу послужило основою для розшифрування механізмів взаємодії між шляхами внутрішньоклітинної сигналізації, що регулюють процеси клітинної проліферації, запалення, тромбозу, апоптозу, ремоделювання і фіброзу при серцево-судинних захворюваннях. Мережевий аналіз коекспресії генів, проведений на основі мікрочипових даних щодо ідентифікації білків периферичної крові (за допомогою програмного забезпечення DAVID i аналітичного пакета SubpathwayMiner, а також бібліотеки генів Limmoc для аналізу мікрочіпових даних) у пацієнтів із ішемічною хворобою серця показав, що 20 специфічних модулів (із загального інтерактомного пакета - 3711) були пов’язані зі шляхами сигналізації, характерними для гіпертрофічної кардіоміопатії [33]. До того ж, 30 топ-генів були відібрані як ключові одиниці головного модуля (кластеру) контролю активності антиоксидантного ферменту — глюкозо-6-фосфатдегідрогенази (G6PD), недостатні рівні якого були пов'язані 3 дисфункцією ендотелію, підвищеною судинною жорсткістю і розвитком артеріальної гіпертензії.

За даними Стокгольмського багатоцентрового дослідження повногеномного аналізу експресії генів атеросклерозу [38], методом кластеризації функціонально пов'язаних генів було визначено так званий модуль атеросклерозу («альфа модуль» з 128 генів), що включає генетичні фактори ризику ішемічної хвороби серця. Наприклад, домени TEML (transendothelial migration of leukocytes), LIM (LDB2 - LIM domain biding 2), що виявилися привабливими мішенями при лікуванні атеросклерозу.

Інші дослідники застосували мережевий аналіз для визначення прогнозу після інфаркту міокарда $[48,62]$. Відомо, що ішемічне посткондиціювання завдяки кардіопротекторному механізму здійснює захист міокарда після інфаркту шляхом зниження проявів ішемії. Біоінформаційний аналіз дав можливість оцінити ступінь залучення мережевих білків у реакції захисту після інфаркту міокарда. Виявлено також експресію HSP90, арил-вуглеводневого рецептора (AhR) і бета-тубуліну, що беруть участь як молекули сигнальної трансдукції у відновних процесах у міокарді. Автори вважають [48], що поліпшення серцевої функції після ішемічного посткондиціювання (підвищення фракції викиду лівого шлуночка) в постінфарктному періоді обумовлено зменшенням пошкодження кардіоміоцитів завдяки зниженій регуляції AhRсигналізації і сприяє скороченню розмірів зони інфаркту. Виявилося, що інформація, закодована в мережевій структурі білків запалення, може зумовити клінічний результат після інфаркту міокарда [27]. Автори запропонували специфічну панель генів біомаркерних білків (TRAF2, SHKBP1 i UBC), а також модулі (асоційовані з запаленням) зі значною часткою регуляторів транскрипції, 
включаючи набір мікроРНК, який володіє точною прогностичною релевантністю в клініці гострої коронарної недостатності.

Системний підхід все частіше став використовуватися при вивченні нових патогенетичних механізмів, що лежать в основі первинної кардіоміопатії, а також міжклітинної (фібробласти-моноцити) взаємодії при серцевих аритміях [14]. Досягнуто певних успіхів в оцінці процесу ремоделювання кардіоміоцитів [16] і в ідентифікації біомаркерів при вірусному ендокардиті [12], а також в протеомному профілюванні стрес-білків після ішемічнореперфузійної альтерації міокарда [48].

В окремих випадках системний підхід застосовується для критичного аналізу даних, отриманих у дослідженнях загальногеномних асоціацій (GWAS - genome-wide association study) генетичних варіантів при дилатаційній кардіоміопатії. Системні GWA-дослідження даних включають близько 280000 варіантів генів. Порівняння з контролем у 909 пацієнтів з дилатаційною кардіоміопатією (на основі використання бази даних Кіотської енциклопедії генів і геномів — Kyoto Encyclopedia of Genes and Genomes (KEGG, https:// www.genome.jp/kegg/), що включає 285 сигнальних шляхів), виявило статично значущі відмінності між групами пацієнтів із даною кардіологічною патологією [41].

На завершення слід також відзначити подібності та відмінності стратегій «мережевої медицини» і «онтології знань».

Термін «онтологія» в нинішньому трактуванні і особливо стосовно штучного інтелекту вживається в контексті з такими поняттями, як концептуалізація знання, моделі знань, системи, засновані на знаннях. При цьому під концептуалізацією розуміється процес переходу від подання проблемної

\section{Література.}

1. Амосов Н. М. О возможностях кибернетики в медицине / Н. М. Амосов, О. П. Минцер, Б. Л. Палец // Кардиология. - 1977. — № 7. - С. 19-25.

2. Залесский В. Н. Протеомный анализ секрета мезенхимальных стволовых клеток / В. Н. Залесский // Мезенхимальные и опухолевые стволовые клетки: механизмы иммуновоспалительной модуляции стволовых клеток при персонализированной клеточной реабилитации больных с мультифакторными и онкогематологическими заболеваниями : монография / А. С. Тимченко, В. Н. Залесский. - К. : Між- області на природній мові до точної специфікації цього опису на деякій формальній мові, орієнтованій на комп’ютерне уявлення.

Отже, онтологія — це формально представлені концептуалізовані знання про предметну область.

Онтологія на сьогодні виключно широко застосовується в біологічних і медичних дослідженнях, але якщо мережева медицина орієнтується на двовимірний простір (в окремих випадках три-, чотиривимірний), то в онтологіях зазвичай застосовуються багатовимірні образи. Тому наукові та клінічні моделі більш орієнтовані на мережеві моделі, а освітні — на онтології.

\section{Висновки.}

1. Мережева медицина необхідна для кращого розуміння патогенезу захворювань на системному рівні. Функціональні взаємозалежності між молекулярними компонентами в клітині людини та при захворюваннях рідко є наслідком аномалії в одному гені, але відображають комплексні аномалії внутрішньоклітинної мережі. Нові інструменти мережевої медицини пропонують платформу для систематичного вивчення не тільки молекулярної складності конкретного захворювання (що приводить до ідентифікації модулів і шляхів захворювання), але також і молекулярних відносин між явно вираженими (патогенетичними) фенотипами.

2. Мережева медицина й онтологія знань мають багато спільного, як у стратегії створення, так і в технологіях використання. Проте завдання багатовимірного моделювання сьогодні переважно виконуються в стратегії «онтологія знань». Те ж можна сказати і про освіту, де онтологічні рішення більш популярні.

регіональний видавничий центр «МЕДІНФОРМ», 2018. - C. 275-306.

3. Минцер О. П. Новые информационные технологии в медицине / О. П. Минцер // Журнал практ. врача. - 2008. - № 3. - С. 22-33.

4. Мінцер О. П. Концептуально-технологічні підходи в створенні єдиного медичного освітнього проекту / О. П. Мінцер // Мед. інформатика та інженерія. 2015. - № 1. - C. 5-8.

5. Albert R. Statistical mechanics of complex networks / R. Albert, A. L. Barabasi // Rev. Mod. Phys. - 2002. — Vol. 74, No. 1. - P. 47-97. 
6. A million peptide motifs for the molecular biologist / P. Tompa, W. E. Davey, T. J. Gibson, M. M. Babu // Mol. Cell. — 2014. — Vol. 55, No. 2. — P. 161-169.

7. An empirical framework for binary interactome mapping / K. Venkatesan, J. F. Rual, A. Vazquez [et al.] // Nature Methods. — 2008. — Vol. 6, No. 1. — P. 83-90.

8. A system biology approach reveals a link between systemic cytokines and skeletal muscle energy metabolism in rodent / P. K. Davidsen, J. M. Herbert, P. Antczak [et al.] // Genome Med. - 2014 - Vol. 6, No. 8. - P. 59.

9. Arrell D. K. Network systems biology for drug discovery / D. K. Arrell, A. Terzic // Clin. Pharmacol. — 2010. Vol. 88(1). — P.120-125.

10. Barabási A. L. Network medicine: a networkbased approach to human disease / A. L. Barabási, N. Gulbahce, J. Lascalzo // Nat. Rev. Genet. - 2011. - Vol. 12, No. 1. - P. 56-68.

11. Barabási A. L. Network medicine - from obesity to the "diseasome" / A. L. Barabási // N. Engl. J. Med. 2007. - Vol. 357, No. 4. — P. 404-407.

12. Bioinformatics multivariate analysis determine a set of phase-specific biomarker candidates in a novel mouse model for viral myocarditis / S. Omura, E. Kawai, F. Sato [et al.] // Circ. Cardiovasc. Genet. — 2014. — Vol. 7, No. 4. - P. 444-454.

13. Börner K. Network science / K. Börner, S. Sanyal, A. Vespignani // Annual review of information science and technology. - 2007. — Vol. 41, No. 1. - P. 537-607.

14. Brown T. R. Computational approaches to understanding the role of fibroblast-monocyte interaction in cardiac arrhythmogenesis // T. R. Brown, T. Krogh-Madsen, D. J. Christini // Biomed. Res. Int. — 2015. — Vol. 2015. - P. 465714.

15. Caldarelli G. Scale-free networks / G. Caldarelli. Oxford : Oxford University Press, 2007. — 336 p.

16. Cardiac transcriptome and dilated cardiomyopathy genes in zebrafish / Y. H. Shih, Y. Zhang, Y. Ding [et al.] // Circ. Cardiovasc. Genet. - 2015. — Vol. 8, No. 2. - P. 261-269.

17. Corbi-Verge C. Motif mediated protein-protein interactions as drug targets / C. Corbi-Verge, P. M. Kim // Cell Commun. Signal. — 2016. — Vol. 14. — P. 8.

18. Disease networks. Uncovering disease-disease relationships through the incomplete interactome / J. Menche, A. Sharma, K. M. Kitsak [et al.] // Science. — 2015. - Vol. 347, No. 6224. - P. 1257601.

19. dpPAF: an integrative database of protein / S. Ullah, S. Lin, Y. Xu [et al.] // Sci. Rep. — 2016. — Vol. 6. P. 23534.

20. Eisenberg E. Preferential attachment in the protein network evolution / E. Eisenberg, E. Y. Levanon // Phys. Rev. Lett. - 2003. — Vol. 91, No. 13. — P. 138701.

21. Erler J. T. Network medicine strikes a blow against breast cancer / J. T. Erler, R. Linding // Cell. — 2012. Vol. 149, No. 4. - P. 731-733.
22. Evolutionary rate in the protein interaction network / $\mathrm{H}$. B. Fraser, A. E. Hirsh, L. M. Steinmetz [et al.] // Science. - 2002. — Vol. 296, No. 5568. - P. 750-752.

23. Gibson D. G. Programming biological operation systems: genome design, assembly and activation / D. G. Gibson // Nat. Methods. — 2014. — Vol. 11, No. 5. - P. 521-526.

24. Hanahan D. The hallmarks of cancer / D. Hanahan, R. A. Weinberg // Cell. —2000. — Vol. 100, No. 1. — P. 57-70.

25. Henney A. A network solution / A. Henney, G. SupertiFurga // Nature. —2008. — Vol. 455, No. 7214. — P. 730-731.

26. Hood L. Systems biology and p4 medicine: past, precut future / L. Hood // Rambam Maimonides Med. J. 2013. - Vol. 4, No. 2. - P. e0012.

27. Information encoded in a network inflammation protein predicts clinical outcome after MI / F. J. Azuaje, S. Rodius, L. Zhang [et al.] // BMC Med. Genomics. 2011. - Vol. 4. - P. 59.

28. Integrating network reconstruction with mechanistic modeling to predict cancer therapies / M. Halasz, B. N. Kholodenko, W. Kolch, T. Santra // Sci. Signal. — 2016 — Vol. 9, No. 455. - P. ra114.

29. Kitano H. A robustness-based approach to systemsoriented drug design / H. A. Kitano // Nat. Rev. Drug. Discov. -2007. - Vol. 6, No. 3. - P. 202-210.

30. Korcsmaros T. Next generation of network medicine: interdisciplinary signaling approach / T. Korcsmaros, M. V. Schneider, G. Superti-Furga // Intergr. Biol. (Camb). — 2017. - Vol. 9, No. 2. - P. 97-108.

31. Lethality and centrality in protein networks / H. Jeong, S. P. Mason, A. L. Barabási, Z. N. Oltvai //Nature. 2001. - Vol. 411. - P. 41-42.

32. Linear motif atlas for phosphorylation-dependent signaling / M. L. Miller, L. J. Jensen, F. Diella [et al.] // Sci. Signal. - 2008. - Vol. 1, No. 35. — P. ra2.

33. Liu J. Weighted gene co-expression network analysis identifies specific modules and hub genes related to CAD / J. Liu, L. Jing, X. Tu // BMC Cardiovasc. Disord. 2016. - Vol. 16. - P. 54.

34. Loscalzo J. Network medicine. Comlex systems in human disease and therapeutics / J. Loscalzo, A. L. Barabási, E. K. Silverman (Eds). - Cambridge : Harvard Univ. Press. — 2017. — 448 pp.

35. Mapping the human phosphatome on growth pathways / F. Sacco, P. F. Gherardini, S. Paoluzi [et al.] // Mol. Syst. Biol. - 2012. — Vol. 8. - P. 603.

36. McKusick’s Online Mendelian Inheritance in Man (OMIM®) / J. Amberger, C. A. Bocchini, A. F. Scott, A. Hamosh // Nucleic Acids Res. - 2009. — Vol. 37. - P. D793-796.

37. Mészáros B. Prediction of protein binding regions in disordered protein / B. Mészáros, I. Simon, Z. Dosztányi // PLoS Comput Biol. — 2009. — Vol. 5, No. 5. P. e1000376. 
38. Multi-organ expression profiling uncovers a gene module in coronary artery disease involving transendothelial migration of leukocytes and LIM Domain Binding 2: The Stockholm Atherosclerosis Gene Expression (STAGE) Study / S. Hägg, J. Skogsberg, J. Lundström [et al.] // PLoS Genet. - 2009. - Vol. 5, No. 12. P. e1000754.

39. Network-based tools for the identification of novel drug targets / I. J. Farkas, T. Korcsmáros, I. A. Kovács [et al.] // Sci. Signal. - 2011. — Vol. 4, No. 173. — Pt3.

40. Novel signatures of cancer-associated fibroblast / B. Bozóky, A. Savchenko, P. Csermely [et al.] // Int. J. Cancer. - 2013. - Vol. 133, No. 2. - P. 286-293.

41. Pathway-based variant enrichment analysis on the example of dilated cardiomyopathy / C. Backes, B. Meder, A. Lai [et al.] // Hum. Genet. — 2016. Vol. 135, No. 1. - P. 31-40.

42. Pawson T. Network medicine / T. Pawson, R. Linding // FEBS Lett. — 2008. — Vol. 582, No. 8. — P. 12661270.

43. Positive selection of tyrosine loss in metazoan evolution / C. S. Tan, A. Pasculescu, W. A. Lim [et al.] // Science. — 2009. - Vol. 325, No. 5948. - P. 1686-1688.

44. Prathipati P. Systems biology approaches to a rational drug discovery paradigm / P. Prathipati, K. Mizuguchi // Curr. Top. Med. Chem. — 2016. — Vol. 16, No. 9. — P. 1009-1025.

45. Probing genetic overlap among complex human phenotypes / A. Rzhetsky, D. Wajngurt, N. Park, T. Zheng // Proc. Natl. Acad Sci USA. - 2007. Vol. 104, No. 28. - P. 11694-11699.

46. Protein-protein interaction generate hidden feedback and feedforward loops to trigger bistable switches, oscillations and biphasic dose-responses / T. M. Varusai, W. Kolch, B. N. Kholodenko, L. K. Nguyen // Mol. Biosyst. - 2015. — Vol. 11, No. 10. - P. 2750-2762.

47. Pysz M. A. Molecular imaging: current status and emerging strategies / M. A. Pysz, S. S. Gambhir, J. K. Willmann // Clin. Radiol. — 2010. — Vol. 65, No. 7. - P. 500-516.

48. Reperfusion-triggered stress protein response in the myocardium blocked by post-conditioning. Systems biology pathway analysis highlights the key role of the canonical aryl-hydrocarbon receptor pathway / G. Vilahur, V. Cubedo, L. Casani [et al.] // Eur. Heart J. 2013. — Vol. 34, No. 27. — P. 2062-2093.

49. Santra T. Navigation the multilayered organization of eukaryotic signaling: a new trend in data integration / T. Santra, W. Kolch, B. N. Kholodenko // PLoS Comput. Biol. — 2014. — Vol. 10, No. 2. — P. e1003385.

50. Scaffolds: interaction platforms for cellular signalling circuits / A. Zeke, M. Lukasc, W. A. Lim, A. Reményi // Trends Cell Biol. — 2009. — Vol. 19, No. 8. P. 364-374.

51. Signaling by protein phosphatases and drug development: a systems-centred view / L. K. Nguyen, D. Matallanas,
D. R. Croucher [et al.] // FEBS J. — 2013. - Vol. 280, No. 2. - P. 751-765.

52. SignaLink 2 - a signaling pathway resource with multi-layered regulatory networks / D. Fazekas, M. Koltai, D. Türei [et al.] // BMC Syst. Biol. — 2013. — Vol. 7. - P. 7.

53. Stolovitzky C. Dialogue on reverse-engineering assessment and methods: the DREAM of high throughput pathway inference / C. Stolovitzky, D. Monroe, A. Califano // Ann. N. Y. Acad. Sci. USA. - 2007. - Vol. 1115. - P. 1-22.

54. Structure and dynamics of molecular network: a novel paradigm of drug discovery: a comprehensive review / P. Csermely, T. Korcsmáros, H. J. Kiss, [et al.] // Pharmacol. Ther. — 2013. — Vol. 138, No. 3. - P. 333-408.

55. Sung M. H. Live cell imaging and system biology / M. H. Sung, J. G. McNally // Wiley Interdiscip. Rev. Syst. Biol. Med. — 2011. — Vol. 3, No. 2. — P. 167-182.

56 . Systems biochemistry in practice: experimenting with modeling and understanding, with regulation and control / H. V. Westerhoff, M. Verma, M. Nardelli [et al.] // Biochem. Soc. Transl. — 2010. — Vol. 38, No. 5. — P. 1189-1196.

57. Systems pharmacology: an opinion on how to turn the impossible into grand challenges / H. V. Westerhoff, S. Nakayawa, T. D. Mondeel, M. Barberis // Drug Discov. Today Technol. — 2015. — Vol. 15. - P. 23-31.

58. The eukaryotic linear motif resource ELM: 10 years / H. Dinkel, K. Van Roey, S. Michael [et al.] // Nucleic Acids Res. - 2014. — Vol. 42, Database issue. P. D259-266.

59. The human disease network / K. I. Goh, M. E. Cusick, D. Valle [et al.] // PNAS. - 2007. — Vol. 104, No. 21. - P. 8685-8690.

60. The long-HER study: clinical and molecular analysis of patients with HER2+ advanced breast cancer who become long-term survivors with trastuzumab-based therapy / A. Gámez-Pozo, R. M. Pérez Carrión, L. Manso [et al.] // PLoS One. - 2014. — Vol. 9, No. 10. - P. e109611.

61. The treatment-naive microbiome in new-onset Crohn's disease / D. Gevers, S. Kugathasan, L. A. Denson [et al.] // Cell. Host Microbe. — 2014. — Vol. 15, No. 3. — P. 382-392.

62. Understanding different facets of cardiovascular diseases based on model systems to human studies: a proteomic and metabolomics perspective / T. Basak, S. Varshney, S. Akhtar, S. Sengupta // J. Proteomics. — 2015. Vol. 127, Pt A. - P. 50-60.

63. Uniformly curved signal pathways reveal tissuespecific cross-talks and support drug target discovery / T. Korcsmáros, I. J. Farkas, M. S. Szalay [et al.] // Bioinformatics. — 2010. — Vol. 26, No. 16. — P. 20422050. 
64. Villaveces J. M. Tools for visualization and analysis of molecular network, pathways and -omix data / J. M. Villaveces, P. Koti, B. H. Habermann // Adv. Appl. Bioinform. Chem. - 2015. - Vol. 8. - P. 11-22.

65. Vojisavljevic V. Prediction of intrinsically disordered regions in protein using signal processing methods: application to heat-shock proteins / V. Vojisavljevic, E. Pirogova // Med. Biol. Eng. Comput. - 2016. — Vol. 54, No. 12. - P. 1831-1844.

66. Zauzoni B. A network medicine approach to human disease / B. Zauzoni, M. Soler-López, P. Aloy // FEBS Lett. — 2009. — Vol. 583, No. 11. — P. 1759-1765.

67. Zhao Y. Modification-specific proteomics: strategies for characterization of post-translational modifications using enrichments techniques / Y. Zhao, O. N. Jensen // Proteomics. - 2009. - Vol. 9, No. 20. - P. 4632-4641.

68. Zhu X. Getting connected: analysis and principles of biological networks / X. Zhu, M. Gerstein, M. Snyder // Genes and Development. - 2007. - Vol. 21, No. 9. - P. 1010-1024.

\section{References.}

1. Amosov, N. M., Mintser, O. P., Palets, B. L. (1977). O vozmozhnostyakh kibernetiki v meditsine [On the possibilities of cybernetics in medicine]. Kardiologiya (Cardiology), 7, 19-25.

2. Zalesskii, V. N. (2018). Proteomnyi analiz sekreta mezenkhimal'nykh stvolovykh kletok [Proteomic analysis of the secretion of mesenchymal stem cells]. In Timchenko A. S., Zalesskii V. N. Mezenkhimal'nye i opukholevye stvolovye kletki: mekhanizmy immunovospalitel'noi modulyatsii stvolovykh kletok pri personalizirovannoi kletochnoi reabilitatsii bol'nykh s mul'tifaktornymi i onkogematologicheskimi zabolevaniyami [Mesenchymal and tumor stem cells: mechanisms of immune-inflammatory modulation of stem cells in personalized cellular rehabilitation of patients with multifactorial and oncohematological diseases]: monograph (pp. 275-306). Kyiv: Mizhregional'nii vidavnichii tsentr «MEDINFORM» (Interregional Publishing Center «MEDINFORM»).

3. Mintser, O. P. (2008). Novye informatsionnye tekhnologii v meditsine [New information technologies in medicine]. Zhurnal prakt. vracha (Journal of Practical Physician), 3, 22-33.

4. Mintser, O. P. (2015). Kontseptual'no-tekhnologichni pidkhodi v stvorenni edinogo medichnogo osvitn'ogo proektu [Conceptual and technological approaches to the creation of an unified medical educational project]. Medichna informatika ta inzheneriya (Medical Informatics and Engineering), 1, 5-8.

5. Albert, R., Barabasi, A. L. (2002). Statistical mechanics of complex networks. Rev. Mod. Phys., 74(1), 47-97. doi: 10.1103/RevModPhys.74.47.

6. Tompa, P., Davey, W. E., Gibson, T. J., \& Babu, M. M. (2014). A million peptide motifs for the molecular biologist. Mol. Cell., 55(2), 161-169. doi: 10.1016/j. molcel.2014.05.032.

7. Venkatesan, K., Rual, J. F., Vazquez, A. Stelzl, U., Lemmens, I., Hirozane-Kishikawa, T., ... Vidal, M. (2008). An empirical framework for binary interactome mapping. Nature Methods, 6(1), 83-90. doi: 10.1038/ nmeth.1280.

8. Davidsen, P. K., Herbert, J. M., Antczak, P., Clarke, K., Ferrer, E., Peinado, V. I., ... Falciani. F. (2014). A system biology approach reveals a link between systemic cytokines and skeletal muscle energy metabolism in rodent. Genome Med., 6(8), 59. doi: 10.1186/s13073014-0059-5.

9. Arrell, D. K., \& Terzic, A. (2010). Network systems biology for drug discovery. Clin. Pharmacol., 88(1), 120-125. doi: 10.1038/clpt.2010.91.

10. Barabási, A. L., Gulbahce, N., \& Lascalzo, J. (2011). Network medicine: a network-based approach to human disease. Nat. Rev. Genet., 12(1), 56-68. doi: 10.1038/ nrg2918.

11. Barabási, A. L. (2007). Network medicine - from obesity to the "diseasome”. N. Engl. J. Med., 357(4), 404-407. doi: 10.1056/NEJMe078114.

12. Omura, S., Kawai, E., Sato, F., Martinez, N. E., Chaitanya, G. V., Rollyson, P. A., ... Tsunoda, I. (2014). Bioinformatics multivariate analysis determine a set of phase-specific biomarker candidates in a novel mouse model for viral myocarditis. Circ. Cardiovasc. Genet., 7(4), 444-454. doi: 10.1161/ CIRCGENETICS.114.000505.

13. Börner, K., Sanyal, S., \& Vespignani, A. (2007). Network science. Annual review of information science and technology, 41(1), 537-607, doi: 10.1002/ aris.2007.1440410119.

14. Brown, T. R., Krogh-Madsen, T., \& Christini, D. J. (2015). Computational approaches to understanding the role of fibroblast-monocyte interaction in cardiac arrhythmogenesis. Biomed. Res. Int., 2015, 465714. doi: 10.1155/2015/465714.

15. Caldarelli, G. (2007). Scale-free networks. Oxford: Oxford University Press.

16. Shih, Y. H., Zhang, Y., Ding, Y., Ross, C. A., Li, H., Olson, T. M., \& Xu, X. (2015). Cardiac transcriptome and dilated cardiomyopathy genes in zebrafish. Circ. Cardiovasc. Genet., 8(2), 261-269. doi: 10.1161/ CIRCGENETICS.114.000702.

17. Corbi-Verge, C., \& Kim, P. M. (2016). Motif mediated protein-protein interactions as drug targets. Cell Commun. Signal., 14, 8. doi: 10.1186/s12964-016-01314.

18. Menche, J., Sharma, A., Kitsak, K. M., Ghiassian, S. D., Vidal, M., Loscalzo, J., \& Barabási, A. L. (2015). Disease networks. Uncovering disease-disease relationships through the incomplete interactome. Science, 347(6224), 1257601. doi: 10.1126/science.1257601. 
19. Ullah, S., Lin, S., Xu, Y., Deng, W., Ma, L., Zhang, Y., Liu, Z., \& Xue, Y. (2016). dpPAF: an integrative database of protein. Sci. Rep., 6, 23534. doi: 10.1038/ srep23534.

20. Eisenberg, E., \& Levanon, E. Y. (2003). Preferential attachment in the protein network evolution. Phys. Rev. Lett., 91(13), 138701. doi: 10.1103/ PhysRevLett.91.138701.

21. Erler, J. T., \& Linding, R. (2012). Network medicine strikes a blow against breast cancer. Cell, 149(4), 731-733. doi: 10.1016/j.cell.2012.04.014.

22. Fraser, H. B., Hirsh, A. E., Steinmetz, L. M., Scharfe, C., \& Feldman, M. W. (2002). Evolutionary rate in the protein interaction network. Science, 296(5568), 750-752. doi: 10.1126/science.1068696.

23. Gibson, D. G. (2014). Programming biological operation systems: genome design, assembly and activation. Nat. Methods, 11(5), 521-526. doi: 10.1038/nmeth.2894.

24. Hanahan, D., \& Weinberg, R. A. (2000). The hallmarks of cancer. Cell, 100(1), 57-70.

25. Henney, A., \& Superti-Furga, G. (2008). A network solution. Nature, 455(7214), 730-731. doi: 10.1038/455730a.

26. Hood, L. (2013). Systems biology and p4 medicine: past, precut future. Rambam Maimonides Med. J., 4(2), e0012. doi: 10.5041/RMMJ.10112.

27. Azuaje, F. J., Rodius, S., Zhang, L., Devaux, Y., \& Wagner, D. R. (2011). Information encoded in a network inflammation protein predicts clinical outcome after MI. BMC Med. Genomics, 4, 59 doi: 10.1186/1755-87944-59.

28. Halasz, M., Kholodenko, B. N., Kolch, W., \& Santra, T. (2016). Integrating network reconstruction with mechanistic modelling to predict cancer therapies. Sci. Signal., 9(455), ra114. doi: 10.1126/scisignal.aae0535.

29. Kitano, H. (2007). A robustness-based approach to systems-oriented drug design. Nat. Rev. Drug. Discov., 6(3), 202-210. doi: 10.1038/nrd2195.

30. Korcsmaros, T., Schneider, M. V., \& Superti-Furga, G. (2017). Next generation of network medicine: interdisciplinary signaling approach. Intergr. Biol. (Camb.), 9(2), 97-108. doi: 10.1039/c6ib00215c.

31. Jeong, H., Mason, S. P., Barabási, A. L., \& Oltvai, Z. N. (2001). Lethality and centrality in protein networks. Nature, 411, 41-42. doi: 10.1038/35075138.

32. Miller, M. L., Jensen, L. J., Diella, F., Jørgensen, C., Tinti, M., Li, L., ... Linding, R. (2008). Linear motif atlas for phosphorylation-dependent signaling. Sci. Signal., 1(35), ra 2. doi: 10.1126/scisignal.1159433.

33. Liu, J., Jing, L., \& Tu, X. (2016). Weighted gene coexpression network analysis identifies specific modules and hub genes related to CAD. BMC Cardiovasc. Disord., 16, 54. doi: 10.1186/s12872-016-0217-3.

34. Loscalzo, J., Barabási, A. L., \& Silverman, E. K. (Eds). (2017). Network medicine. Comlex systems in human disease and therapeutics. Cambridge: Harvard Univ. Press.

35. Sacco, F., Gherardini, P. F., Paoluzi, S., SaezRodriguez, J., Helmer-Citterich, M., Ragnini-Wilson, A., Castagnoli, L., \& Cesareni, G. (2012). Mapping the human phosphatome on growth pathways. Mol. Syst. Biol., 8, 603. doi: 10.1038/msb.2012.36.

36. Amberger, J., Bocchini, C. A., Scott, A. F., \& Hamosh, A. (2009). McKusick's Online Mendelian Inheritance in Man (OMIM®). Nucleic Acids Res., 37, D793-796. doi: 10.1093/nar/gkn665.

37. Mészáros, B., Simon, I., \& Dosztányi, Z. (2009). Prediction of protein binding regions in disordered protein. PLoS Comput. Biol., 5(5), e1000376. doi: 10.1371/journal.pcbi.1000376.

38. Hägg, S., Skogsberg, J., Lundström, J., Noori, P., Nilsson, R., Zhong, H., ... Björkegren, J. (2009). Multiorgan expression profiling uncovers a gene module in coronary artery disease involving transendothelial migration of leukocytes and LIM Domain Binding 2: The Stockholm Atherosclerosis Gene Expression (STAGE) Study. PLoS Genet., 5(12), e1000754. doi: 10.1371/journal.pgen.1000754.

39. Farkas, I.J., Korcsmáros, T., Kovács, I. A., Mihalik, Á., Palotai, R., Simkó, G. I., ... Csermely, P. (2011). Network-based tools for the identification of novel drug targets. Sci. Signal. , 4(173), Pt3. doi: 10.1126/ scisignal.2001950.

40. Bozóky, B., Savchenko, A., Csermely, P., Korcsmáros, T., Dúl, Z., Pontén, F., Székely, L., \& Klein, G. (2013). Novel signatures of cancer-associated fibroblast. Int. J. Cancer, 133(2), 286-293. doi: 10.1002/ijc.28035.

41. Backes, C., Meder, B., Lai, A., Stoll, M., Rühle, F., Katus, H. A., \& Keller, A. (2016). Pathway-based variant enrichment analysis on the example of dilated cardiomyopathy. Hum. Genet., 135(1), 31-40. doi: 10.1007/s00439-015-1609-7.

42. Pawson, T., \& Linding, R. (2008). Network medicine. FEBS Lett., 582(8), 1266-1270. doi: 10.1016/j. febslet.2008.02.011.

43. Tan, C. S., Pasculescu, A., Lim, W. A., Pawson, T., Bader, G. D., \& Linding, R. (2009). Positive selection of tyrosine loss in metazoan evolution. Science, 325(5948), 1686-1688. doi: 10.1126/science.1174301.

44. Prathipati, P., \& Mizuguchi, K. (2016). Systems biology approaches to a rational drug discovery paradigm. Curr. Top. Med. Chem., 16(9), 1009-1025.

45. Rzhetsky, A., Wajngurt, D., Park, N., \& Zheng, T. (2007). Probing genetic overlap among complex human phenotypes. Proc. Natl. Acad. Sci. USA, 104(28), 11694-11699. doi: 10.1073/pnas.0704820104.

46. Varusai, T.M., Kolch, W., Kholodenko, B. N., \& Nguyen, L. K. (2015). Protein-protein interaction generate hidden feedback and feedforward loops to trigger bistable switches, oscillations and biphasic dose-responses. Mol. Biosyst., 11(10), 2750-2762. doi: 10.1039/c5mb00385g. 
47. Pysz, M. A., Gambhir, S. S., \& Willmann, J. K. (2010). Molecular imaging: current status and emerging strategies. Clin. Radiol., 65(7), 500-516. doi: 10.1016/j. crad.2010.03.01/1.

48. Vilahur, G., Cubedo, V., Casani, L., Padro, T., SabateTenas, M., Badimon, J. J., \& Badimon, L. (2013). Reperfusion-triggered stress protein response in the myocardium blocked by post-conditioning. Systems biology pathway analysis highlights the key role of the canonical aryl-hydrocarbon receptor pathway. Eur. Heart J., 34(27), 2062-2093. doi: 10.1093/eurheartj/ehs211.

49. Santra, T., Kolch, W., \& Kholodenko, B. N. (2014). Navigation the multilayered organization of eukaryotic signaling: a new trend in data integration. PLoS Comput. Biol., 10(2), e1003385. doi: 10.1371/journal. pcbi.1003385.

50. Zeke, A., Lukasc, M., Lim, W. A., \& Reményi, A. (2009). Scaffolds: interaction platforms for cellular signaling circuits. Trends Cell Biol., 19(8), 364-374. doi: 10.1016/j.tcb.2009.05.007.

51. Nguyen, L. K., Matallanas, D., Croucher, D. R., von Kriegsheim, B. A., \& Kholodenko, N. (2013). Signaling by protein phosphatases and drug development: a systems-centred view. FEBS J., 280(2), 751-765. doi: 10.1111/j.1742-4658.2012.08522.x.

52. Fazekas, D., Koltai, M., Türei, D., Módos, D., Pálfy, M., Dúl, Z., ... Korcsmáros, T. (2013). SignaLink 2 - a signaling pathway resource with multilayered regulatory networks. BMC Syst.Biol., 7, 7. doi: 10.1186/1752-0509-7-7.

53. Stolovitzky, C., Monroe, D., \& Califano, A. (2007). Dialogue on reverse-engineering assessment and methods: the DREAM of high throughput pathway inference. Ann. N. Y. Acad. Sci. USA, 1115, 1-22. doi: 10.1196/annals.1407.021.

54. Csermely, P., Korcsmáros, T., Kiss, H. J., London, G., \& Nussinov, R. (2013). Structure and dynamics of molecular network: a novel paradigm of drug discovery: a comprehensive review. Pharmacol. Ther., 138(3), 333-408. doi: 10.1016/j.pharmthera.2013.01.016.

55. Sung, M. H., \& McNally, J. G. (2011). Live cell imaging and system biology. Wiley Interdiscip. Rev. Syst. Biol. Med., 3(2), 167-182. doi: 10.1002/wsbm.108.

56. Westerhoff, H. V., Verma, M., Nardelli, M., Adamczyk, M., van Eunen, K., Simeonidis, E., \& Bakker, B. M. (2010). Systems biochemistry in practice: experimenting with modeling and understanding, with regulation and control. Biochem. Soc. Transl., 38(5), 1189-1196. doi: 10.1042/BST0381189.

57. Westerhoff, H. V., Nakayawa, S., Mondeel, T. D., \& Barberis, M. (2015). Systems pharmacology: an opinion on how to turn the impossible into grand challenges. Drug Discov. Today Technol., 15, 23-31. doi: 10.1016/j. ddtec.2015.06.006.

58. Dinkel, H., Van Roey, K., Michael, S., Davey, N. E., Weatheritt, R. J., Born, D., ... Gibson, T. J. (2014).
The eukaryotic linear motif resource ELM: 10 years. Nucleic Acids Res., 42(Database issue), D259-266. doi: 10.1093/nar/gkt1047.

59. Goh, K. I., Cusick, M. E., Valle, D., Childs, B., Vidal, M., Barabási, A. L. (2007). The human disease network. PNAS, 104(21), 8685-8690. doi: 10.1073/ pnas.0701361104.

60. Gámez-Pozo, A., Pérez Carrión, R. M., Manso, L., Crespo, C., Mendiola, C., López-Vacas, R., ... Zamora, P. (2014). The long-HER study: clinical and molecular analysis of patients with HER2+ advanced breast cancer who become long-term survivors with with trastuzumabbased therapy. PLoS One, 9(10), e109611. doi: 10.1371/ journal.pone.0109611.

61. Gevers, D., Kugathasan, S., Denson, L. A., VázquezBaeza, Y., Van Treuren, W., Ren, B., ... Xavier, R. J. (2014). The treatment-naive microbiome in new-onset Crohn's disease. Cell. Host Microbe, 15(3), 382-392. doi: 10.1016/j.chom.2014.02.005/.

62. Basak, T., Varshney, S., Akhtar, S., \& Sengupta, S. (2015). Understanding different facets of cardiovascular diseases based on model systems to human studies: a proteomic and metabolomics perspective. J. Proteomics, 127(Pt A), 50-60. doi: 10.1016/j.jprot.2015.04.027.

63. Korcsmáros, T., Farkas, I. J., Szalay, M. S., Rovó, P., Fazekas, D., Spiró, Z., ... Csermely, P. 2010.Uniformly curved signal pathways reveal tissue-specific cross-talks and support drug target discovery. Bioinformatics, 26(16), 2042-2050. doi: 10.1093/bioinformatics/btq310.

64. Villaveces, J. M., Koti, P., \& Habermann, B. H. (2015). Tools for visualization and analysis of molecular network, pathways and -omix data. Adv. Appl. Bioinform. Chem., 8, 11-22. doi: 10.2147/AABC. S63534.

65. Vojisavljevic, V., \& Pirogova, E. (2016). Prediction of intrinsically disordered regions in protein using signal processing methods: application to heat-shock proteins. Med. Biol. Eng. Comput., 54(12), 1831-1844. doi: 10.1007/s11517-016-1477-x.

66. Zauzoni, B., Soler-López, M., \& Aloy, P. (2009). A network medicine approach to human disease. FEBS Lett., 583(11), 1759-1765. doi: 10.1016/j. febslet.2009.03.001.

67. Zhao, Y., \& Jensen, O. N. (2009). Modificationspecific proteomics: strategies for characterization of post-translational modifications using enrichments techniques. Proteomics, 9(20), 4632-4641. doi: 10.1002/ pmic.200900398.

68. Zhu, X., Gerstein, M., \& Snyder, M. (2007). Getting connected: analysis and principles of biological networks. Genes and Development, 21(9), 1010-1024. doi: 10.1101/gad.1528707. 